\title{
DIVERSITY OF FUNGI IN SEEDS OF HYMENAEA STIGNOCARPA AND HYMENAEA COURBARIL BEFORE AND AFTER FUNGICIDE TREATMENTS
}

\author{
INCIDÊNCIA DE FUNGOS NO TRATAMENTO DE SEMENTES DE HYMENAEA \\ STIGNOCARPA E HYMENAEA COURBARIL
}

\begin{abstract}
Nayara Cecília Rodrigues COSTA ${ }^{1}$; Fábio Janoni CARVALHO ${ }^{1}$; Fernando Cezar JULIATTI ${ }^{2}$; Mariana Viana CASTRO ${ }^{3}$; Walter Vieira da CUNHA ${ }^{4}$

1. Programa de Pós-Graduação em Agronomia - Fitotecnia, Instituto de Ciências Agrárias, Universidade Federal de Uberlândia - UFU, Uberlândia, MG, Brasil. nayaracrcosta@ hotmail.com; 2. Professor Titular, Instituto de Ciências Agrárias, Universidade Federal de Uberlândia. juliatti@ufu.br; 3. Graduação em Agronomia, Centro Universitário de Patos de Minas, Patos de Minas, MG, Brasil; 4. Professor Titular, Centro Universitário de Patos de Minas, Patos de Minas, MG, Brasil.
\end{abstract}

\begin{abstract}
The recovery of degraded areas led to an increase of native forest seedlings production. Jatobado-cerrado (Hymenaea stignocarpa Mart.) and jatoba-da-mata (Hymenaea courbaril L.), native species of the Brazilian Cerrado, are widely used for the recovery of this biome. Although forest species present a diversity of pathogens disseminated by seeds, few studies have been published and no study was found for jatoba. Because the seed is one of the main forms of pathogen dissemination, the aim of our work was to evaluate the natural incidence of fungi in seed lots of jatoba-do-cerrado and jatoba-da-mata and the performance of different fungicides for seed treatment recommendation. The experiment was carried out at the Genetics and Biotechnology Laboratory of the University Center of Patos de Minas. Two chemical treatments were submitted in the seeds and then divided into seven replicates of 15 seeds for each species. The first treatment was with the active principle thiophanate-methyl and fluazine, commercial name Certeza ${ }^{\circledR}$, in the dose of $145 \mathrm{~mL}$ of the product in $100 \mathrm{~kg}$ of seeds. The second treatment was with fludioxonil, commercial name Maxim ${ }^{\circledR} \mathrm{XL}$, in the dose of $100 \mathrm{~mL}$ of the product in $100 \mathrm{~kg}$ of seeds. There was a third treatment corresponded to the control (without seed treatment). The visual analyzes were performed after eight days on each seed with a magnifier to verify the presence of developing fungal colonies. The growth fungi fructifications were observed using a stereomicroscope. The found fungi species were: Aspergillus sp., Fusarium sp., Mucor sp., Penicillium sp., Pestalotiopsis sp., Phomopsis sp., Rhizoctonia sp., Rhizopus sp. and Trichoderma sp. It occurred interaction between seed treatment and species for Aspergillus sp., Fusarium sp., Mucor sp., Phomopsis sp., Rhizoctonia sp. and Trichoderma sp. For Penicillium sp., Pestalotiopsis sp. and Rhizopus sp., only the isolated factors were significant. Jatoba-do-cerrado seeds had a higher incidence than jatoba-da-mata seeds in all the found fungi. Certeza ${ }^{\circledR}$ and Maxim $^{\circledR}$ XL have potential in seed treatment for the species. The fungicide Certeza ${ }^{\circledR}$ was more efficient to control the pathogenic fungi in seed treatment.
\end{abstract}

KEYWORDS: Jatoba-do-cerrado. Jatoba-da-mata. Fludioxonil. Thiophanate-methyl. Fluazinan.

\section{INTRODUCTION}

The recovery of degraded areas led to an increase of native forest seedlings production. Because of that, many nurseries began to specialize in the production of forest seedlings. Seeds are collected from natural biomes and then sold to the nurseries (CARVALHO FILHO et al., 2003). Jatoba-do-cerrado (Hymenaea stignocarpa Mart.) and jatoba-da-mata (Hymenaea courbaril L.), native species of the Brazilian Cerrado, are widely used for the recovery of this biome (BRANDÃO; GAVILANES, 1992).

The jatoba belongs to the Caesalpiniaceae family, reaching up a height of 20 meters with a trunk of one meter in diameter, with logging possibility (SAMPAIO et al., 2015). The fruits have a farinaceous pulp that provides flour with protein value equivalent to corn meal, with culinary use (ORSI et al., 2012). It is not very demanding on fertility and soil moisture, with adaptive ability for different edaphoclimatic conditions, being an important element for the composition of heterogeneous reforestations and in parks afforestation (SCABORA et al., 2011).

The improvement of seedling production techniques has great relevance because of the environment degradation increases. Researches about native forest species for the accomplishment of forest recomposition are necessary (SAMPAIO et al., 2015). Seed sanity is the key component for healthy seedlings formation and helps to prevent the spread of seed pathogens. However, although forest species present a diversity of pathogens disseminated by seeds, few studies have been published (CARNEIRO, 1986; 1990; NETTO; FAIAD, 1995; MUNIZ et al., 2007), and for jatoba, no publications have been found. The knowledge about pathogens disseminated by seeds is the first process for a correct seed treatment. 
The seed treatment, eliminating the pathogens of the seeds or protecting them against the action of environmental pathogens, has great importance in the development of vigorous and healthy plants. The chemical seed treatment is economic, easy to perform and considered safe for the human and environment. Due to the small number of products added in the seeds and the direct contact with the target site, this method is not harmful for the environment when compared to conventional disease treatment controls (MITTAR, 1986; MENTEN; MORAES, 2010). Among the seed treatment chemicals, the active ingredients fludioxonil and thiophanate-methyl + fluazinan are widely used in several crops of agricultural interest, like soybean, corn, bean and cotton (AGROFIT, 2003; SILVA et al., 2011).

Because the seed is one of the main forms of plant diseases dissemination, the aim of our work was to evaluate the natural incidence of fungi in seed lots of jatoba (H. stignocarpa and H. courbaril) and the performance of different fungicides for seed treatment recommendation.

\section{Contents}

The experiment was carried out at the Genetics and Biotechnology Laboratory (GENEB) of the University Center of Patos de Minas (UNIPAM), located in the city of Patos de Minas, Minas Gerais. Seeds of $H$. stigonocarpa and $H$. courbaril were donated by the State Forestry Institute (IEF), located in the same city. The seeds were collected in the years of 2016 and 2017, respectively, and then they were duly conditioned and stored in a cold room $\left(3{ }^{\circ} \mathrm{C}, 24 \% \mathrm{RH}\right)$ before the analysis.

Seed sanity evaluations were adapted for jatoba based on "Regras para Análise de Sementes" prescriptions (BRASIL, 2009). Pathogen detection was determined using the blotter test method. Acrylic gerboxes $(11 \times 11 \times 3.5 \mathrm{~cm})$, previously washed and disinfested with $70 \%$ alcohol solution, were used.

Two chemical treatments were submitted in the seeds and then divided into seven replicates of 15 seeds for each species. The first treatment was with the active principle thiophanate-methyl and fluazine, commercial name Certeza ${ }^{\circledR}$, in the dose of $145 \mathrm{~mL}$ of the product in $100 \mathrm{~kg}$ of seeds. The second treatment was with fludioxonil, commercial name Maxim ${ }^{\circledR}$ XL, in the dose of $100 \mathrm{~mL}$ of the product in $100 \mathrm{~kg}$ of seeds. There was a third treatment corresponded to the control (without seed treatment).
The market fungicides are not recommended for forest species treatment, so the fungicide doses were established according to the agricultural crops recommendation. The fungicides were applied dry, then mixed with the corresponding forest seeds into a plastic bag and shaken manually for five minutes.

Three sheets of paper filter were sterilized in an autoclave $\left(120^{\circ} \mathrm{C}\right.$ and $1 \mathrm{~atm}$ for $\left.20^{\prime}\right)$, placed and moistened with distilled water for each gerbox. Thereafter, the gerboxes were taken into a laminar flow cabinet and the seeds were arranged on the filter paper. The boxes were sealed with transparent acrylic lid and placed in a Biochemical Oxygen Demand (BOD) germination chamber type, set at $20 \pm 2{ }^{\circ} \mathrm{C}$ and with a 12 hour photoperiod (white fluorescent light).

The visual analyzes were performed after eight days on each seed with the help of a magnifier to verify the presence of developing fungal colonies. In the presence of fungi, the growth fungi fructifications were observed using a stereomicroscope with magnification from 10 to $100 X$. In some observations, the fragments of the fungal structures were transferred to Petri dishes containing BDA medium for the preparation of microscope slides for optical microscopy to confirm the genus of the fungi. The results were expressed as fungi incidence percentage.

The identified fungus incidence data was adjusted to a Generalized Linear Model (GLM), with a binomial distribution and logit link function. The effects were subjected to deviance analysis (ANODEV) using the Chi-square test $\left(\mathrm{X}^{2}\right)$ at 0.05 of significance, and when significant differences were found, the means were compared with Tukey's test at 0.05 of significance.

After the stereomicroscope and optical microscopy evaluations, the following fungi were found: Aspergillus sp., Fusarium sp., Mucor sp., Penicillium sp., Pestalotiopsis sp., Phomopsis sp., Rhizoctonia sp., Rhizopus sp. and Trichoderma sp. It occurred interaction between seed treatment and species for Aspergillus sp., Fusarium sp., Mucor sp., Phomopsis sp., Rhizoctonia sp. and Trichoderma sp. (Table 1). For Penicillium sp., Pestalotiopsis sp. and Rhizopus sp., only the isolated factors were significant (Table 2).

For jatoba-da-mata, the seed treatment with Certeza $^{\circledR}$ and Maxim $^{\circledR}$ XL were efficient in the control of Aspergillus sp. and Fusarium sp., preventing fungi proliferation of $16.19 \%$ for Aspergillus sp. and $45.71 \%$ for Fusarium sp. The untreated seeds showed incidence of Mucor sp., Phomopsis sp. and Rhizoctonia sp., although the 
seeds treated with Maxim ${ }^{\circledR}$ XL accentuated fungi incidence. The same behavior was not observed for Certeza $^{\circledR}$ product, which did not allow the development of these fungi. For jatoba-do-cerrado, efficiency in seed treatments were identified for Aspergillus sp., Mucor sp. and Trichoderma sp. with
Maxim $^{\circledR}$ XL; for Fusarium sp. with Certeza ${ }^{\circledR}$; and for Phomopsis sp. and Rhizoctonia sp. with both products. For Mucor sp., a higher incidence with Certeza $^{\circledR}$ was observed when compared to the control.

Table 1. Percentage means for fungi incidence of Aspergillus sp., Fusarium sp., Mucor sp., Phomopsis sp., Rhizoctonia sp. and Trichoderma sp. in jatoba seeds submitted to different seed treatments.

\begin{tabular}{lllll}
\hline \multirow{2}{*}{ Treatment } & Aspergillus $\mathrm{sp}$. & \multicolumn{3}{c}{ Fusarium $\mathrm{sp}}$. \\
& H. courbaril & H. stignocarpa & H. courbaril & H. stignocarpa \\
\hline Certeza $^{\circledR}$ & $0.00 \mathrm{Aa}$ & $37.14 \mathrm{ABb}$ & $0.00 \mathrm{Aa}$ & $0.00 \mathrm{Aa}$ \\
Maxim $^{\circledR} \mathrm{XL}$ & $3.81 \mathrm{Aa}$ & $22.85 \mathrm{Ab}$ & $0.00 \mathrm{Aa}$ & $11.14 \mathrm{Bb}$ \\
Control & $16.19 \mathrm{Ba}$ & $45.71 \mathrm{Bb}$ & $24.76 \mathrm{Bb}$ & $5.71 \mathrm{Ba}$ \\
\hline
\end{tabular}

\begin{tabular}{lllll}
\hline \multirow{2}{*}{ Treatment } & Mucor $\mathrm{sp}$. & & Phomopsis $\mathrm{sp}$. \\
& H. courbaril & H. stignocarpa & H. courbaril & H. stignocarpa \\
\hline Certeza $^{\circledR}$ & $0.00 \mathrm{Aa}$ & $27.61 \mathrm{Bb}$ & $0.00 \mathrm{Aa}$ & $4.76 \mathrm{Ab}$ \\
Maxim $^{\circledR}$ XL & $9.53 \mathrm{Bb}$ & $0.00 \mathrm{Aa}$ & $10.47 \mathrm{Ba}$ & $10.47 \mathrm{Aa}$ \\
Control & $0.00 \mathrm{Aa}$ & $0.00 \mathrm{Aa}$ & $0.00 \mathrm{Aa}$ & $41.90 \mathrm{Bb}$ \\
\hline
\end{tabular}

\begin{tabular}{lllll}
\hline \multirow{2}{*}{ Treatment } & Rhizoctonia $\mathrm{sp}$. & & Trichoderma $\mathrm{sp}$. & \\
& H. courbaril & H. stignocarpa & H. courbaril & H. stignocarpa \\
\hline Certeza $^{\circledR}$ & $0.00 \mathrm{Aa}$ & $14.29 \mathrm{Ab}$ & $0.00 \mathrm{Aa}$ & $20.00 \mathrm{Bb}$ \\
Maxim $^{\circledR} \mathrm{XL}$ & $6.67 \mathrm{Ba}$ & $11.42 \mathrm{Aa}$ & $9.52 \mathrm{Ba}$ & $5.71 \mathrm{Aa}$ \\
Control & $0.00 \mathrm{Aa}$ & $46.7 \mathrm{Bb}$ & $7.62 \mathrm{Ba}$ & $20.00 \mathrm{Bb}$
\end{tabular}

Means followed by same letters, uppercase in columns and lowercase in rows, are not different by the Tukey's test $(0.05$ of significance).

Seed treatments with Certeza ${ }^{\circledR}$ and Maxim $^{\circledR}$ XL were efficient in Penicillium sp. and Rhizopus sp. control, reaching a complete control when the incidence was $27.51 \%$ for Penicillium and $54.54 \%$ for Rhizopus. For Pestalotiopsis sp., a fungus that was not incident on the control, a small presence was observed applying Maxim ${ }^{\circledR}$ XL. Moreover, it was verified that these three genera of fungi were incident only in $H$. stignocarpa (Table 2).

Table 2. Percentage means for fungi incidence of Penicillium sp., Pestalotiopsis sp. and Rhizopus sp. in jatoba seeds submitted to different seed treatments.

\begin{tabular}{|c|c|c|c|}
\hline Treatment & Penicillium sp. & Pestalotiopsis sp. & Rhizopus sp. \\
\hline Certeza $^{\circledR}$ & $0.00 \mathrm{~A}$ & $0.00 \mathrm{~A}$ & $0.00 \mathrm{~A}$ \\
\hline $\operatorname{Maxim}^{\circledR} \mathrm{XL}$ & $7.00 \mathrm{~A}$ & $4.77 \mathrm{~B}$ & $0.00 \mathrm{~A}$ \\
\hline Control & 27.51B & $0.00 \mathrm{~A}$ & $54.54 \mathrm{~B}$ \\
\hline Species & Penicillium sp. & Pestalotiopsis sp. & Rhizopus sp. \\
\hline H. courbaril & $00.01 \mathrm{~A}$ & $0.00 \mathrm{~A}$ & $0.00 \mathrm{~A}$ \\
\hline H. stignocarpa & $22.35 \mathrm{~B}$ & $0.25 \mathrm{~A}$ & $25.03 \mathrm{~B}$ \\
\hline
\end{tabular}

Means followed by same uppercase letters in columns are not different by the Tukey's test ( 0.05 of significance).

There are few studies about the pathogens transmission by seeds in forest species, despite the great number of pathogens that can be found with them. Many of these pathogens are genera of fungi that cause problems for agronomic crops (SANTOS et al., 2000). Phytopathogens may be associated with seeds on their surface, in their interior or in a mixture, with the most varied forms of propagation, from spores to resistance structures. Phytosanitary aspects have been difficult because of the lack of research information on the fungi pathogenicity associated with forest species seeds (LAZAROTTO et al., 2013), revealing the importance of these studies. 
The major problems associated with diseases occur during the germination and seedlings formation in nurseries, usually caused by a fungus. The fungi frequency occurs because of the fruit traits and seed harvest, processing and storage (NETTO; FAIAD, 1995; SILVA, 2003; SILVA et al., 2011). Due to the inaccessibility of the fruits in tall trees, the seeds harvest is made from fruits or even seeds dropped on the ground. In the soil, under the trees, part of the fruits and seeds are colonized by fungi influencing the germination (SANTOS et al., 2000).

In forest species, there are worldwide reports identifying the genera Aspergillus, Fusarium, Mucor, Penicillium, Pestalotiopsis, Phomopsis, Rhizoctonia, Rhizopus, Trichoderma and others (LASCA et al., 1971; CARNEIRO, 1986; MITTAR, 1986; CHARCHAR et al., 2003). Jatoba seed sanity studies are scarce. However, the highest occurrence of diseases was verified in leaves of $H$. courbaril when compared with other six forest species. The genus Pestalotiopsis was identified in H. courbaril leaves (ASSIS et al., 2010) and Phomopsis in H. stignocarpa (CHARCHAR et al., 2003). In lumbers of $H$. courbaril, the incidence of Fusarium sp., Penicillium sp., Rhizoctonia sp. and Trichoderma sp. was eminent (SACCOMAN et al., 2016). This is the first record about the presence of pathogens in two species of jatoba seeds.

In addition, the genus Aspergillus and Penicillium were found in pata-de-vaca (Bauhinia variegata) (SENEME et al., 2006), paricá (Schizolobium amazonicum) (OLIVEIRA et al., 2012), and manduirana (Senna mancrathera) (PIVETA et al., 2018); Fusarium in pata-de-vaca (SENEME et al., 2006), amendoim-bravo (Pterogyne nitens) (NASCIMENTO et al., 2006) and favela (Dimorphandra mollis) (ARAÚJO et al., 2009); Pestalotiopsis in paricá (OLIVEIRA et al., 2012); Phomopsis sp. in favela (ARAÚJO et al., 2009); Rhizoctonia in amendoim-bravo (NASCIMENTO et al., 2006) and manduirana (PIVETA et al., 2018); Rhizopus in pata-de-vaca (SENEME et al., 2006) and Trichoderma in manduirana (PIVETA et al., 2018). This is the first report about the incidence of Mucor sp. in species of the Caesalpiniaceae family.

Seeds treated with Maxim $^{\circledR}$ XL had the incidence higher than the control for Fusarium sp. in H. stignocarpa; and for Mucor sp., Phomopsis sp., Rhizoctonia sp. and Trichoderma sp. in $H$. courbaril. For Mucor and Trichoderma genera, the result is explained by the chemical peculiarities of the fungicide that do not control these fungi. Possibly, the fungicide allowed the growth of these fungi due to the great incidence and variability of genera present in the jatoba seeds. The control of Aspergillus sp. and Fusarium sp. in H. courbaril and Aspergillus sp., Mucor sp., Phomopsis sp. and Rhizoctonia sp. in H. stignocarpa, favored the fungi growth due to the inhibition of competition.

The importance and efficiency of chemicals in forest seeds treatment is subject of study by researchers. Fungicides with active ingredient carboxim-thiram in the dose of $250 \mathrm{~mL}$ in $100 \mathrm{~kg}$ of seeds, were viable for the control of Alternaria sp., Aspergillus sp., Colletotrichum sp., Fusarium sp. and Penicillium sp. in Chorisia speciosa (SILVA et al., 2003); and Aspergillus sp., Curvularia sp., Penicillium sp. and Trichoderma sp. in Acacia mearnsii (PISSININ et al., 2008).

Silva et al. (2011) showed that chemical molecules captan $(120 \mathrm{~g}$ in $100 \mathrm{~kg}$ of seeds) and thiram (280 g in $100 \mathrm{~kg}$ of seeds) reduced the incidence of the genera Alternaria, Aspergillus, Fusarium and Penicillium in Dalbergia nigra, Handroanthus heptaphyllus and Handroanthus chrysotrichus. In the seeds of Acca sellowiana, different chemical treatments with captan $(160 \mathrm{~g})$, carbendazim $(100 \mathrm{~mL})$, carbendazim + thiram $(300$ $\mathrm{mL})$ and carboxim + thiram (180 g in $100 \mathrm{~kg}$ of seeds) had low or no occurrence of Alternaria sp., Aspergillus sp., Colletotrichum sp., Fusarium sp., Penicillium sp. and Phomopsis sp. (FANTINEL et al., 2015).

Forest seeds pathology deserves a comprehensive scientific space due to the occurrence of fungi that cause damage to quality and seedling production (SILVA et al. 2011), such as Aspergillus, Fusarium, Penicillium, Pestalotiopsis Phomopsis, Rhizoctonia, Rhizopus and Trichoderma, causing seed rot, leading to germination and vigor reduction by deterioration, and death (NETTO; FAIAD, 1995; DHINGRA et al., 2002). Considering the economic and social impacts of several forest species, the chemical seed treatment is an efficient control treatment aimed to reduce diseases in these species.

Jatoba-do-cerrado (H. stignocarpa) seeds have a higher incidence than jatoba-da-mata $(H$. courbaril) seeds in all the found fungi. Certeza ${ }^{\circledR}$ (thiophanate-methyl + fluazine) and Maxim $^{\circledR}$ XL (fludioxonil) have potential in these species seeds treatment. The fungicide Certeza ${ }^{\circledR}$ was more efficient to control the pathogenic fungi in seed treatment. 
RESUMO: A recuperação de áreas degradas levou ao aumento da produção de mudas de espécies florestais nativas. Jatobá-do-cerrado (Hymenaea stignocarpa Mart.) e jatobá-da-mata (Hymenaea courbaril L.), espécies nativas do Cerrado brasileiro, são amplamente utilizadas na recuperação deste bioma. Apesar da diversidade de fungos encontrada em sementes de espécies florestais, poucos são os estudos publicados, e não nenhum relato para o jatobá. Por a semente ser um dos principais meios de disseminação de patógenos, o objetivo do trabalho foi avaliar a incidência natural de fungos em lotes de semente de jatobá-do-cerrado e jatobá-da-mata, e a performance de diferentes fungicidas para a recomendação do tratamento de sementes. O experimento foi realizado no Laboratório de Genética e Biotecnologia do Centro Universitário de Patos de Minas. Dois tratamentos químicos foram realizados nas sementes, que então foram divididas em sete repetições com 15 sementes cada. O primeiro tratamento foi realizado com o princípio ativo tiofanato-metílico e fluazinam, nome comercial Certeza ${ }^{\circledR}$, na dose de $145 \mathrm{~mL}$ do produto para $100 \mathrm{~kg}$ de sementes. O segundo tratamento foi realizado com fludioxonil, nome comercial Maxim ${ }^{\circledR} \mathrm{XL}$, na dose de $100 \mathrm{~mL}$ do produto para $100 \mathrm{~kg}$ de sementes. $\mathrm{O}$ terceiro tratamento correspondeu a testemunha (sem tratamento de sementes). Após oito dias, a análise visual foi realizada com o auxílio de uma lupa para verificar a presença de colônias de fungos. As frutificações dos fungos foram observadas com o auxílio de um microscópio óptico. Após as avaliações, os seguintes fungos foram encontrados: Aspergillus sp., Fusarium sp., Mucor sp., Penicillium sp., Pestalotiopsis sp., Phomopsis sp., Rhizoctonia sp., Rhizopus sp. e Trichoderma sp. Ocorreu interação entre o tratamento de sementes e as espécies para Aspergillus sp., Fusarium sp., Mucor sp., Phomopsis sp., Rhizoctonia sp. e Trichoderma sp. Para Penicillium sp., Pestalotiopsis sp. e Rhizopus sp., apenas os fatores isolados foram significativos. Sementes de jatobá-do-cerrado possuíram maior incidência do que as sementes de jatobá-damata para todos os fungos encontrados. Certeza ${ }^{\circledR}$ e Maxim ${ }^{\circledR}$ XL possuem potencial para o tratamento de sementes de jatobá. O fungicida Certeza ${ }^{\circledR}$ foi mais eficiente para o controle de fungos patogênicos no tratamento de sementes.

PALAVRAS-CHAVE: Jatobá-do-cerrado. Jatobá-da-mata. Fludioxonil. Tiofanato-metílico. Fluazinam.

\section{REFERENCES}

AGROFIT. Ministério da Agricultura, Pecuária e Abastecimento. Sistemas de agrotóxicos fitossanitários. Brasília: Ministério da Agricultura, Pecuária e Abastecimento, 2003. Available at:

$<$ http://agrofit.agricultura.gov.br/agrofit_cons/principal_agrofit_cons>. Access in: 02 fev. 2018.

ARAÚJO, A. V.; SALES, N. L. P.; FERREIRA, I. C. P. V.; BRANDÃO JUNIOR, D.; MARTINS, E. R. Germinação, vigor e sanidade de sementes de fava d'anta (Dimorphandra mollis Benth.) obtidas de frutos coletados no solo e na planta. Revista Brasileira de Plantas Medicinais, Paulínia, v. 11, n. 2, p. 170-175, 2009.

ASSIS, L. A. G.; COELHO NETTO, R. A.; BARBOSA, A. P.; BEZERRA, J. L.; GASPAROTTO, L.; SOUSA, F. M. G. Parasitas fúngicos em espécies florestais nativas da Amazônia Central. Agrotrópica, Ilhéus, v. 22, n. 3, p. 137-144, 2010.

BRANDÃO, M.; GAVILANES, M. L. Espécies arbóreas padronizadoras do Cerrado Mineiro e sua distribuição no Estado. Informe Agropecuário, Belo Horizonte, v. 16, n. 173, p. 5-11, 1992.

BRASIL. Ministério da Agricultura, Pecuária e Abastecimento. Regras para análise de sementes. Ministério da Agricultura, Pecuária e Abastecimento. Secretaria de Defesa Agropecuária. Brasília: MAPA/ACS, 2009. $395 \mathrm{p}$.

CARNEIRO, J. S. Qualidade sanitária de sementes de espécies florestais em Paraopeba, MG. Fitopatologia Brasileira, Brasília, v. 15, n. 1, p. 75-76, 1990.

CARNEIRO, J. S. Micoflora associada às sementes de essências florestais em Paraopeba, MG. Fitopatologia Brasileira, Brasília, v. 11, n. 3, p. 556-557, 1986.

CARVALHO FILHO, J. L. S.; ARRIGONI-BLANK, M. F.; BLANK, A. F.; RANGEL, M. S. A. Produção de mudas de Jatobá (Hymenea courbaril) em diferentes ambientes, recipientes, e composições de substratos.

Cerne, Lavras, v. 9, n. 1, p. 109-118, 2003. 
CHARCHAR, M. J. A.; ANJOS, J. R. N.; MELO, J. T. Infecção natural de jatobá por Phomopsis sp. no Distrito Federal. Fitopatologia Brasileira, Brasília, v. 28, n. 3, p. 316-318, 2003. https://doi.org/10.1590/S0100-41582003000300016

DHINGRA, O. D.; MAIA, C. B.; LUSTOSA, D. C.; MESQUITA, J. B. Seedborne pathogenic fungi that affect seedling quality of red angico (Anadenanthera macrocarpa) trees in Brazil. Journal of Phytopathology, Germany, v. 150, n. 8-9, p. 451- 455, 2002. https://doi.org/10.1046/j.1439-0434.2002.00777.x

FANTINEL, V. C.; OLIVEIRA, L. M. de; CASA, R. T.; da ROCHA, E. C.; SCHNEIDER, P. F.; VICENTE, D. Tratamentos de sementes de goiaba-serrana (Acca sellowiana): efeito na incidência de fungos e na germinação. Revista Brasileira de Biociências, Porto Alegre, v. 13, n. 2, p. 84-89, 2015.

LASCA, C. C.; SAMPAIO, A. P.; CINTRA, A. F. Condições fitossanitárias de sementes importadas de Pinus spp. O Biológico, São Paulo, v. 37, n. 11, p. 287-292, 1971.

LAZAROTTO, M.; MUNIZ, M. F. B.; BELTRAME, R.; SANTOS, A. F.; MÜLLER, J.; ARAÚJO, M. M. Tratamentos biológico e químico em sementes de Cedrela fissilis para controle de Rhizoctonia sp. Cerne, Lavras, v. 19, n. 1, p. 169-175, 2013.

MENTEN, J. O.; MORAES, M. H. D. Tratamento de sementes: histórico, tipos, características e benefícios. Abrates, Londrina, v. 20, n. 3, p. 52-53, 2010.

MITTAR, R. K. Studies on the mycroflora and its control on the seeds of some forests trees: III Eucalyptus hybrid. Malasian Forester, New Zealand, v. 49, n. 2, p. 151-159, 1986.

MUNIZ, M. F. B; SILVA, L. M. E; BLUME, E. Influência da assepsia e do substrato na qualidade de sementes e mudas de espécies florestais. Revista Brasileira de Sementes, Londrina, v. 29, n. 1, p. 140-146, 2007. https://doi.org/10.1590/S0101-31222007000100019

NASCIMENTO, W. M. O. do; CRUZ, E. D.; MORAES, M. H. D.; MENTEN, J. O. M. Qualidade sanitária e germinação de sementes de Pterogyne nitens Tull. (Leguminosae-Caesalpinioideae). Revista Brasileira de Sementes, Londrina, v. 28, n. 1, p. 149-153, 2006. https://doi.org/10.1590/S0101-31222006000100021

NETTO, D. A. M.; FAIAD, M. G. R. Viabilidade e sanidade de sementes de espécies florestais. Revista Brasileira de Sementes, Londrina, v. 17, n. 1, p. 75-80, 1995. https://doi.org/10.17801/0101-

3122/rbs.v17n1p75-80

OLIVEIRA, J. D. de; SILVA, J. B. da; DAPONT, E. C.; SOUZA, L. M. S. de; RIBEIRO, S. A. L. Métodos para detecção de fungos e assepsia de sementes de Schizolobium amazonicum (Caesalpinioideae). Bioscience Journal, Uberlândia, v. 28, n. 6, p. 945-953, 2012.

ORSI, P. R.; BONAMIN, F.; SEVERI, J. A.; SANTOS, R. C.; VILEGAS, W.; HIRUMA-LIMA, C. A.; DISTASI, L. C. Hymenaea stigonocarpa Mart. ex Hayne: a Brazilian medicinal plant with gastric and duodenal anti-ulcer and antidiarrheal effects in experimental rodent models. Journal of Ethnopharmacology, Pretoria, v. 143, n. 1, p. 81-90, 2012. https://doi.org/10.1016/j.jep.2012.06.001

PISSININ, L. Z. Tratamento de sementes e tipos de substratos na produção de mudas de Acacia mearnsii. Cerne, Lavras, v. 14, n. 2, p. 170-176, 2008.

PIVETA, G.; GARCIA, F. A. O.; MUNIZ, M. F. B. Qualidade sanitária e fisiológica de Senna macranthera quando submetida a métodos de superação da dormência. Ciência Florestal (online), Santa Maria, 2018.

SACCOMAN, N. A. F.; TEIXEIRA, S. O.; DAVID, G. Q.; PERES, W. M.; YAMASHITA, O. M. Levantamento de fungos ocorrentes em madeira serrada de jatobá extraída da Amazônia Meridional. Revista de Ciências Agroambientais, Mato Grosso, v. 14, n. 2, p. 100-106, 2016. 
SAMPAIO, M. F.; do COUTO S. R., SILVA, C. A.; SILVA, A. C. A.; da SILVA, A. A. S.; TEIXEIRA, A. L. Influência de diferentes substratos associados a métodos de superação de dormência na germinação e emergência de sementes de jatobá (Hymenaea courbaril L.). Revista Farociência, Rondônia, v. 2, n. 1, p. 11$27,2015$.

SANTOS, A. F. dos; GRIGOLETTI JÚNIOR, A.; AUER, C. G. Transmissão de fungos por sementes de espécies florestais. Floresta, Paraná, v. 30, n. 2, p. 119-128, 2000. https://doi.org/10.5380/rf.v30i12.2360

SCABORA, M. H.; MALTONI, K. L.; CASSIOLATO, A. M. R. Associação micorízica em espécies arbóreas, atividade microbiana e fertilidade do solo em áreas degradadas de cerrado. Ciência Florestal, Santa Maria, v. 21, n. 2, p. 289-301, 2011. https://doi.org/10.5902/198050983232

SENEME, A.M.; POSSAMAI, E.; SCHUTA, L.R.; VANZOLINI-SEGATO, S. Germinação e sanidade de sementes de Bauhinia forficata. Revista Árvore, Viçosa, v. 30, n. 5, p. 719-724, 2006.

SILVA, L. G.; COSMI, F. C.; JESUS JUNIOR, W. C.; de SOUZA, A. F.; MORAES, W. B. Efeito do tratamento químico na sanidade de sementes de espécies florestais. Ciência Florestal, Santa Maria, v. 21, n. 3, p. 473-478, 2011. https://doi.org/10.5902/198050983804

SILVA, R. T. V. Tratamento de sementes e armazenamento na sanidade de sementes de paineira (Chorisia speciosa St. Hil). Semina: Ciências Agrárias, Londrina, v. 24, n. 2, p. 255-260, 2003. 